Article

\title{
Frugivory by Coyotes Decreases the Time to Germination and Increases the Growth of Netleaf Hackberry (Celtis reticulata) Seedlings
}

\author{
Michael T. Stevens * $*$, Sydney Houghton $₫$ and Hannah A. Veltkamp \\ Department of Biology, Utah Valley University, Orem, UT 84058, USA; sydney_olivia@icloud.com (S.H.); \\ hannah.veltkamp@gmail.com (H.A.V.) \\ * Correspondence: michael.stevens@uvu.edu
}

Received: 4 June 2020; Accepted: 1 July 2020; Published: 3 July 2020

\begin{abstract}
Research Highlights: Frugivory by mammals is a common plant-animal interaction, but additional studies that examine the effects of frugivory on woody plants are needed. We show that ingestion of netleaf hackberry (Celtis reticulata Torr.) fruits by coyotes (Canis latrans Say) cuts the time to germination nearly in half and results in seedlings that are taller than the controls. Background and Objectives: Netleaf hackberry is a deciduous shrub to small tree that can be long-lived, but newly established stands are rare. The lack of juvenile hackberry in its native range of southwestern North America could be due to low percentages of germination and seedling survival. We hypothesized that passage through the digestive tract of a coyote would increase the germination and subsequent growth of netleaf hackberry. Materials and Methods: In the Wasatch Mountains of Utah, we collected coyote scats containing visible hackberry fruits and picked fresh fruits from nearby hackberry shrubs. All samples were cleaned and cold-stratified. We sowed 20 seeds from each of the 34 samples into containers in the greenhouse (a total of 680 seeds). We noted the date of emergence and final height of each seedling after 131 days. Results: The germination percentage of the coyote-treatment seeds did not differ from that of the controls. However, the coyote-ingested seeds took just over half as many days to germinate as did the undigested controls (35 days vs. 69 days, respectively; $p<0.001$ ) and the resulting seedlings were $9.5 \%$ taller by the end of the growing season $(6.4 \mathrm{vs} .5 .8 \mathrm{~cm}$, respectively; $p<0.001$ ). Conclusions: Consumption by coyotes can benefit hackberries by enabling their seeds to germinate earlier in the year when conditions are wetter and cooler. The additional time for establishment and growth afforded by frugivory likely increases the fitness of netleaf hackberry seedlings that emerge into the unpredictable conditions of a semi-arid region.
\end{abstract}

Keywords: Celtis reticulata; coyotes; frugivory; germination; growth; hackberries; plant-animal interactions; seed; seedling; Wasatch Mountains

\section{Introduction}

Frugivory by mammals is widespread [1-3], but studies of the effects of frugivory on germination probability, germination timing, and the growth and survival of seedlings are rare [3-5]. Frugivory and the subsequent passage through the gut of an animal can affect fruits by removing pulp (de-inhibition) and affect seed coats via mechanical and chemical scarification [6]. Additionally, the variable treatment that fruits and seeds receive inside an animal's digestive tract can increase the asynchrony of germination [7]. Germination asynchrony can also be introduced at the population level when only a subset of fruits is exposed to frugivory. Asynchronous germination can be beneficial in unpredictable environments and reduce sibling competition [8,9]. However, the effects of frugivory on plants can be beneficial, neutral, or negative [10]. 
Coyotes (Canis latrans Say) are highly frugivorous and commonly consume fruits in the genus Celtis across its range [3]. We sought to understand how the fitness of netleaf hackberry (Celtis reticulata Torr.) is affected when it experiences frugivory by coyotes in terms of its seedlings' germination and growth. Netleaf hackberry fruits are drupes that each contain one seed. They ripen from September to November [11] and are an important source of food for birds [12] as well as coyotes and other small mammals [13].

Netleaf hackberry likely benefits from seed dispersal when its fruits are ingested and defecated in a new location (endozoochory). However, because newly established stands of netleaf hackberry are rare [14], we sought to quantify the effects of frugivory on netleaf hackberry germination and growth-irrespective of the presumed benefits of dispersal. The dearth of newly established stands could be due to low percentages of germination that have been observed in both laboratory $[15,16]$ and field settings $[17,18]$. The hard and thick-walled seeds of netleaf hackberry could impede germination [11] and may be positively affected by passing through the digestive tract of a coyote. We hypothesized that frugivory by coyotes would increase the probability of germination, decrease the time required for germination, and increase growth and survival of netleaf hackberry seedlings.

\section{Materials and Methods}

To test our hypotheses, we collected 17 coyote scats containing visible hackberry fruits from along the Bonneville Shoreline Trail east of Provo, Utah, USA, from 5-7 November 2018, using latex gloves. Each scat location was recorded using a GPS unit. After collecting each scat, we found the closest hackberry shrub and picked a sample of fresh hackberry fruits from it (Figure 1). The fresh-fruit samples are referred to as 17 half-sibling families because they were obtained from 17 known mother shrubs, but their sources of pollen were unknown. All samples were stored in Ziploc bags in the refrigerator. On 12-13 November 2018, we removed the hackberry fruit from the coyote scats and transferred them into 0.25 liter glass jars with lids. On 19 November 2018, we added a 1:5 solution of bleach (6\% sodium hypochlorite) and distilled water to the glass jars and added one drop of dishwashing detergent [19]. We then agitated the jars for ten minutes using a Cole-Palmer (Vernon Hills, IL, USA) orbital shaker on its highest setting. The fruits were then rinsed with tap water for five minutes using a sieve. The fresh hackberries were transferred to the same glass jars and treated similarly. All samples were placed on paper towels in the laboratory to air-dry overnight. Cold stratification began on 20 November 2018. The fruits were wrapped in moist paper towels and placed in Ziploc bags and refrigerated $\left(20^{\circ} \mathrm{C}\right)$ for at least 120 days, as recommended by Bonner [15]. To reduce mold growth (also reported by DeBolt [16]), we rinsed the fruits for one minute in tap water using a sieve and changed the paper towels and Ziploc bags. This was done on 11 January, 6 February, and also on 28 March 2019, immediately before planting. By using intact fruits as our controls, we more closely mimicked the conditions that non-ingested fruits would experience in the field [20]. Comparing intact fruits to the coyote-treatment fruits allowed us to examine the combined effects of de-inhibition (pulp removal) and scarification (seed coat exposure to the mechanical and chemical processes of digestion). 


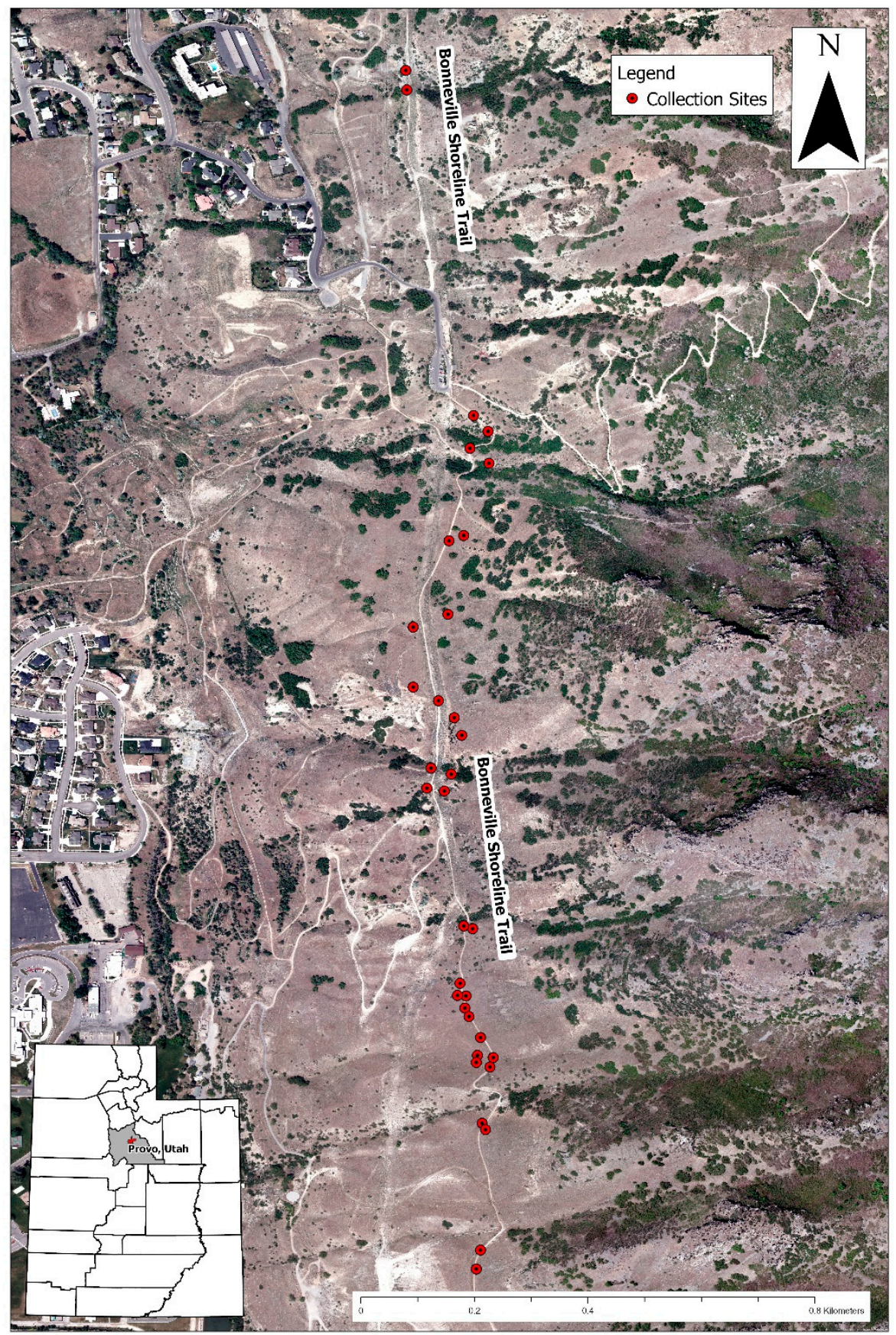

Figure 1. An overhead view of the locations of the 34 netleaf hackberry fruit collection sites (shown with red dots) along the Bonneville Shoreline Trail in foothills of the Wasatch Mountains, east of Provo, Utah, USA. Seventeen collection sites utilized fruits embedded in coyote scats deposited along the trail, while the other sites involved collecting fresh fruit directly from 17 nearby netleaf hackberry shrubs. Collections were done on 5-7 November 2018.

Seeds were planted on 28-29 March 2019 into black containers with a diameter of $3.8 \mathrm{~cm}$, depth of $21 \mathrm{~cm}$, and a volume of $164 \mathrm{~mL}$. The drain holes of the containers were plugged with cotton coil and then filled with Sunshine Mix \#2 potting soil (Sun Gro Horticulture Distribution Inc., Agawam, Massachusetts, USA). A single hackberry fruit (containing one seed) was sown into each container at a depth of $1.5 \mathrm{~cm}[15,17]$. We sowed 20 seeds from each of the 17 coyote scats and 20 seeds from each of the neighboring hackberry shrubs for a total of 680 seeds. Only intact fruits and seeds with no signs of pathogen or insect damage were used [6]. The 680 containers were labeled with plastic 
stakes and randomly positioned into trays that were randomly distributed on a bench in the Utah Valley University greenhouse. In the greenhouse, temperatures were maintained between 21 and $24^{\circ} \mathrm{C}$ and plants received only ambient levels of sunlight. The seeds, and later seedlings, were watered as needed (typically three days/week). On watering days, we checked for newly germinated hackberry seedlings and recorded their date of emergence. On 7 August 2019, we measured the height of each seedling. Only two seedlings germinated after 7 August 2019, and we concluded data collection after two consecutive weeks had passed with no germination [21].

For statistical analyses, we used a chi-square test to compare germination percentages and t-tests to compare days to germination and final heights between coyote-treatment and control seedlings. Analysis of variance (ANOVA) was used to evaluate height differences among the 17 half-sibling families generated using fresh-picked fruit. Although our study was sufficiently replicated, because it took advantage of naturally occurring coyote scats, it was conducted only once and in only one area. As such, care should be taken to avoid over-generalizing our results.

\section{Results}

The overall final percentage of germination (44.6\%) did not differ across the two treatments. The percent germination of hackberry seeds that had passed through the digestive tract of a coyote was $42.7 \%$ and was $46.5 \%$ for fresh-picked fruit $\left(\chi^{2}=0.558, d f=1, p=0.455\right)$. However, the coyote-treatment seeds germinated faster overall, taking just over half as many days as did the seeds from undigested fruit on average ( 35 days vs. 69 days, respectively; $t$-ratio $=41.870, d f=1, p<0.001$; Figure 2). The range of the period of germination for the undigested control seeds was 108 vs. 123 days for the undigested controls and the coyote-treatment seeds combined. The germination range of the combined period was $14 \%$ longer than the range for control seeds alone.

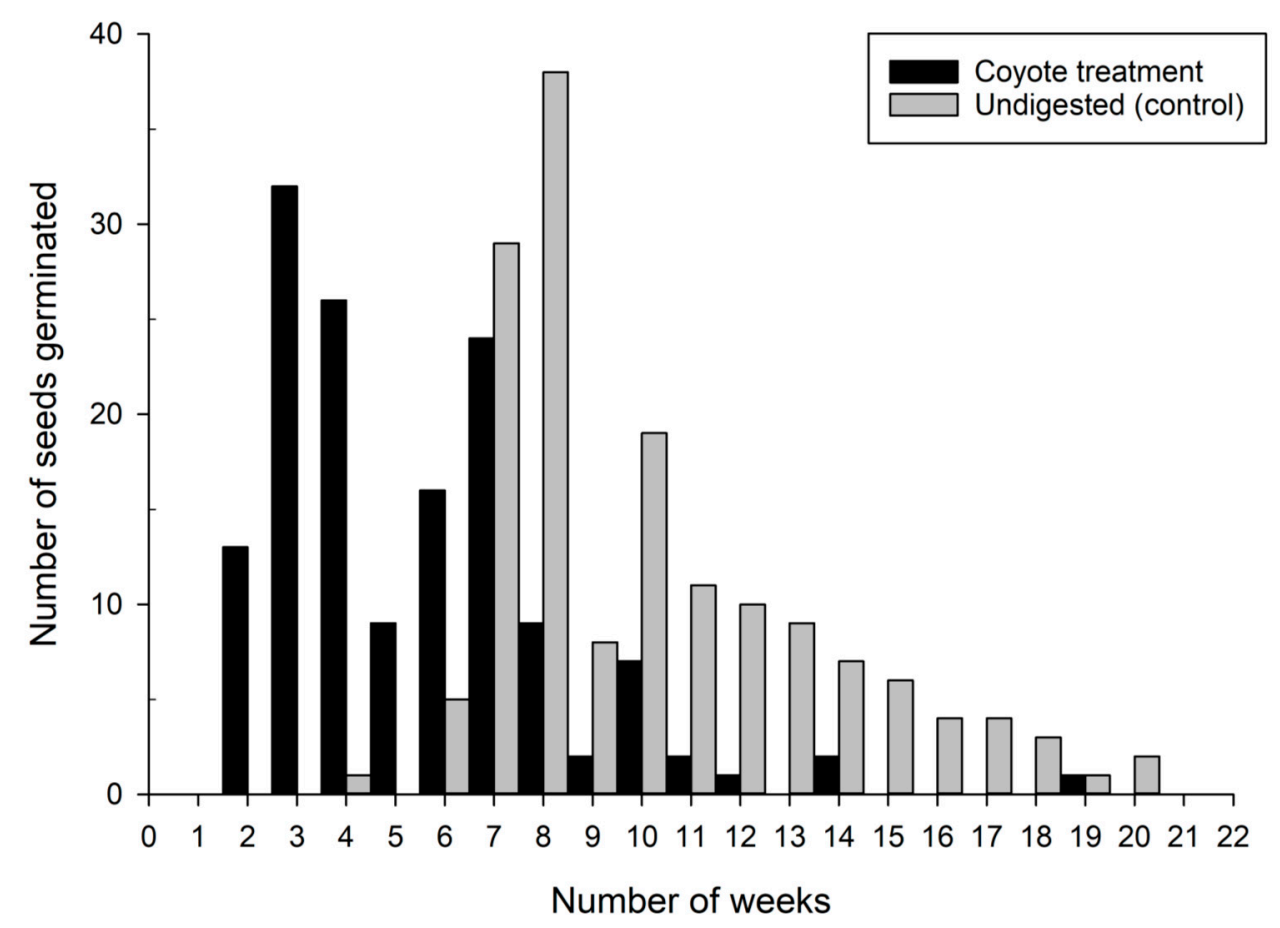

Figure 2. The number of netleaf hackberry seeds that germinated after being planted on 28-29 March 2019 , in the Utah Valley University greenhouse, and the number of weeks it took each to germinate for coyote-treatment fruits $(n=144)$ and undigested controls $(n=157)$.

By 7 August 2019 (131 days after planting), the seedlings from coyote-treatment seeds were $9.5 \%$ taller than seedlings derived from undigested fruit $(6.4 \mathrm{vs} .5 .8 \mathrm{~cm}$, respectively; $t$-ratio $=96.880, d f=1$, $p<0.001$; Figure 3). Among the seedlings from the fresh-picked fruit, there were marginal height 
differences among the 17 half-sibling families $(F$-ratio $=1.539, d f=16, p=0.095)$. Percent survival from germination to 7 August 2019 was extremely high for both the coyote-treatment seedlings (96.6\%) and the undigested controls $(100 \%)$.

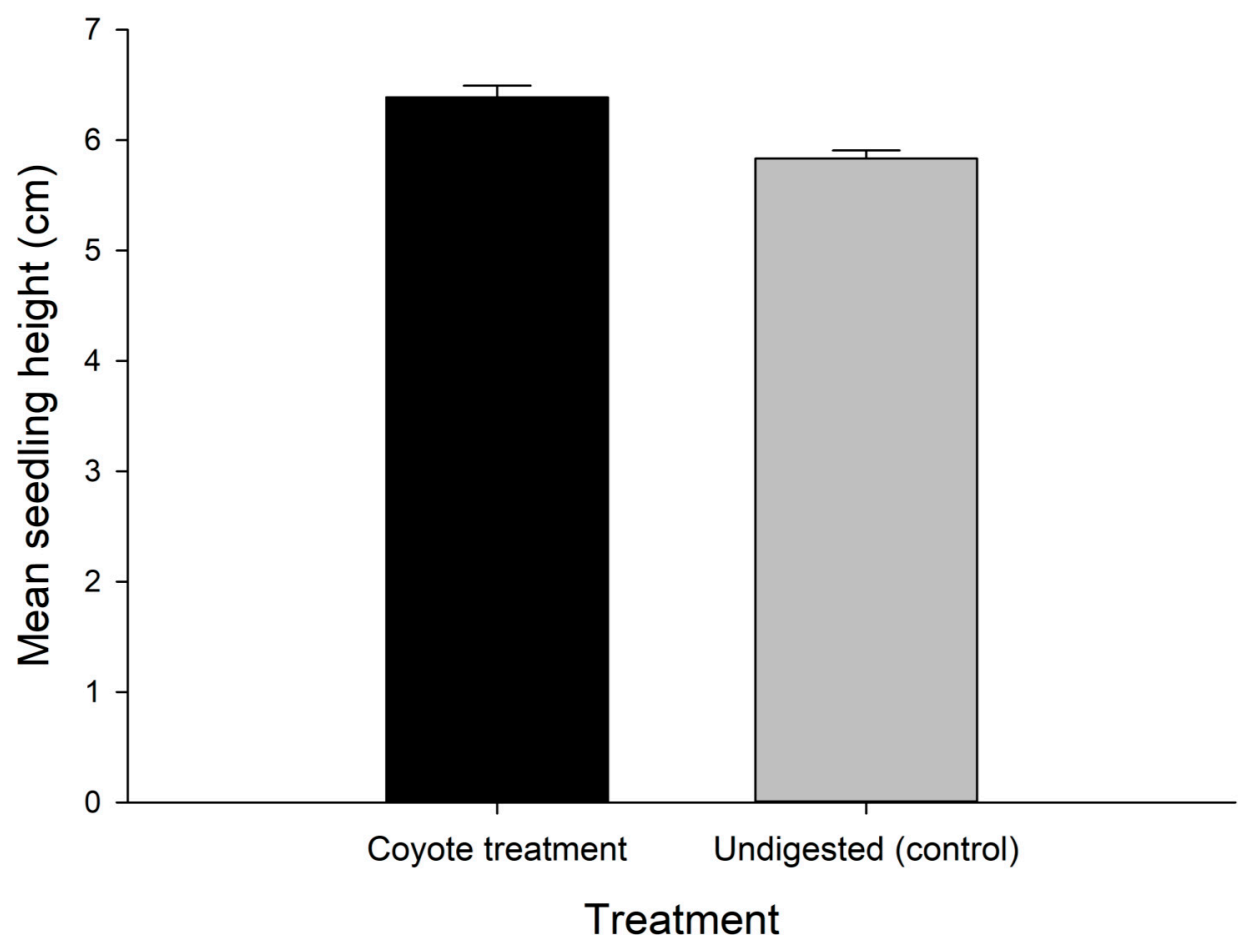

Figure 3. The mean netleaf hackberry seedling height for coyote-treatment fruits $(n=141)$ and undigested controls ( $n=154$ ) on 7 August 2019, 131 days after planting in the Utah Valley University greenhouse. Error bars depict standard errors.

\section{Discussion}

\subsection{Germination Percentage}

Even though there was no effect of the coyote treatment on percent germination, the overall germination percentage (45\%) in this study was quite high. Bonner [15] reported 37\% germination of $C$. reticulata, but other studies have reported much lower percentages of germination in both the laboratory (5\%; [16]) and field (2\%; [17]), even after two years (4\%; [18]). The low percentages of germination in the laboratory study [16] may have been due to the loss of seed viability over time. In the field studies, germination percentages could have been reduced by seed predation [17].

In their meta-analysis of 213 plant species, Traveset and Verdú [22] found an overall positive effect of ingestion on seed germination. However, the effect sizes were less positive for several subcategories that apply to our study (i.e., non-flying mammals, small and medium sizes of seeds, shrubs, shrublands and woodlands, and temperate zones). Cypher and Cypher [23] reported that ingestion by coyotes actually decreased germination percentages for persimmon and American plum seeds and had no effect on pawpaw seeds. They also showed that ingestion by raccoons decreased germination percentages for a congener of C. reticulata (C. occidentalis L.), but they did not examine the effects of ingestion by coyotes on C. occidentalis. Cypher and Cypher [23] speculated that the thick-walled seeds of C. occidentalis would be less affected by gut passage, especially if they moved through the digestive tract quickly due to the laxative effect brought about by fruit-dominated meals [10]. 


\subsection{Germination Timing}

The timing of germination is an important factor that can affect future plant performance in terms of survival, growth, and/or fecundity [24]. Early germination can increase plant fitness in general, and the benefits can be especially pronounced in perennials, such as C. reticulata, as opposed to annuals $[25,26]$. Because many perennials are iteroparous and can reproduce across multiple years, their seeds tend to germinate under the best conditions that a given year offers, whereas annuals, which can only reproduce in the year in which they germinate, tend to spread germination out over time to reduce the risks associated with reproducing in only one year [25].

There are several mechanisms whereby early germination can be beneficial to perennials. Early germinators reduce the time of exposure to seed predation [27]. Once seedlings germinate, early-season growing conditions may offer more abundant water and soil nutrients [28], provide better light environments in deciduous forests [29], cooler temperatures with reduced loads of pathogens and herbivores [29], offer reduced competition with siblings [8,22,25,26], and allow for more time for root establishment before the water stress of summer [21,26,30-32]. In the Wasatch Mountains, establishment before summer drought is particularly key. Previous work on C. reticulata in this area has shown a marked decrease in the survival of seedlings at the onset of summer $[17,18]$. Similar to our results, Traba et al. [5] reported that Mediterranean hackberry (C. australis L.) seeds ingested by red fox germinated earlier than did undigested controls. Although there can be strong directional selection toward early germination, the maintenance of genetic variation for emergence time can benefit populations by allowing them to survive chance events such as spring frosts that disproportionately affect early germinators $[26,33]$.

In terms of asynchrony, the range of the germination period was greater for the combination of the undigested controls and the coyote-treatment seeds when compared to the range of the undigested controls alone. The asynchrony of germination introduced by coyote ingestion confers a fitness advantage for plants like netleaf hackberry that emerge into unpredictable conditions [9] of late spring and early summer in a semi-arid region by increasing the likelihood that a subset of seeds germinates under favorable conditions $[6,26]$.

\subsection{Growth and Survival}

Early germinators tend to grow more than late germinators throughout their lives $[25,26]$ and this is especially true for indeterminately growing trees, such as C. reticulata [34], as opposed to determinately growing trees [31]. Traba et al. [5] reported that Mediterranean hackberry (C. australis) seeds ingested by red fox produced taller seedlings than did undigested controls. DeBolt and McCune [13] reported that for mature C. reticulata, height is an important indicator of growth.

The extremely high percent survival for both the coyote-treatment seeds and the undigested controls might be expected in the ideal conditions of a greenhouse; however, DeBolt [11] indicated that once they reach a sufficient age, young netleaf hackberries are hardy and persist in the field. Perhaps establishment takes multiple years though because Stevens et al. [17] and Stevens and Holland [18] both reported high mortality for one-year-old seedlings in the field-especially in the late summer and fall. The fact that netleaf hackberry is a minor component in many of its habitats $[35,36]$ could be related to the finding that newly established stands of netleaf hackberry are uncommon [14].

\section{Conclusions}

This examination of how frugivory affects the fitness of a woody plant reveals that this plant-animal interaction can benefit $C$. reticulata by decreasing the time to germination and increasing the growth of resulting seedlings-without adversely affecting germination percentages. Earlier germination in a semi-arid region means that seedlings are more likely to emerge into wetter and cooler conditions and allows more time for root establishment and growth before the heat and aridity of summer arrives. Additionally, the greater asynchrony in germination introduced when a portion of fruits are ingested 
by coyotes confers a further fitness advantage through bet-hedging by increasing the probability that a subset of seeds germinates under the most favorable conditions each year. Because netleaf hackberry is consumed by coyotes and a variety of other vertebrates [12,13], it may have evolved generally to benefit from both gut passage and dispersal. The ecological interaction between coyotes and netleaf hackberry may be particularly important for maintaining hackberry in the communities where it is currently found or even for hackberry range expansion as the range of coyotes expands [3]. The potential for coyote-facilitated range expansion into wetter and cooler areas (both at higher latitudes and higher elevations) is particularly important for netleaf hackberry in light of climate change. Finally, a better understanding of frugivory contributes to our comprehension of plant-animal interactions and community ecology in general.

Author Contributions: M.T.S.: conceptualization, data curation, formal analysis, investigation, supervision, writing - original draft. S.H.: funding acquisition, investigation, visualization, writing-review and editing. H.A.V.: funding acquisition, investigation, writing-review and editing. All authors have read and agreed to the published version of the manuscript.

Funding: This research was funded by the Scholarly Activities Committee of the College of Science at Utah Valley University; grant number SHS058.

Conflicts of Interest: The authors declare no conflict of interest.

\section{References}

1. $\quad$ van der Pijl, L. Principles of Dispersal in Higher Plants, 3rd ed.; Springer: Berlin, Germany, 1982.

2. Howe, H.F.; Smallwood, J. Ecology of seed dispersal. Annu. Rev. Ecol. Syst. 1982, 13, 201-228. [CrossRef]

3. Willson, M.F. Mammals as seed-dispersal mutualists in North America. Oikos 1993, 67, 159-176. [CrossRef]

4. Herrera, C.M. Plant-vertebrate seed dispersal systems in the Mediterranean: Ecological, evolutionary, and historical determinants. Annu. Rev. Ecol. Syst. 1995, 26, 705-727. [CrossRef]

5. Traba, J.; Arrieta, S.; Herranz, J.; Clamagirand, M.C. Red fox (Vulpes vulpes L.) favour seed dispersal, germination and seedling survival of Mediterranean hackberry (Celtis australis L.). Acta Oecol. 2006, 30, $39-45$.

6. Fedriani, J.M.; Delibes, M. Functional diversity in fruit-frugivore interactions: A field experiment with Mediterranean mammals. Ecography 2009, 32, 983-992. [CrossRef]

7. Izhaki, I.; Safriel, U. The effect of some Mediterranean scrubland frugivores upon germination patterns. J. Ecol. 1990, 78, 56-65. [CrossRef]

8. Nilsson, P.; Fagerström, T.; Tuomi, J.; Åström, M. Does seed dormancy benefit the mother plant by reducing sib competition? Evol. Ecol. 1994, 8, 422-430. [CrossRef]

9. Simons, A.M. Selection for increased allocation to offspring number under environmental unpredictability. J. Evol. Biol. 2007, 20, 813-817. [CrossRef]

10. Murray, K.; Russell, S.; Picone, C.; Winnett-Murray, K.; Sherwood, W.; Kuhlmann, M. Fruit laxatives and seed passage rates in frugivores: Consequences for plant reproductive success. Ecology 1994, 75, 989-994. [CrossRef]

11. DeBolt, A.M. Celtis reticulata Torr. In Wildland Shrubs of the United States and Its Territories: Thamnic Descriptions; Francis, J.K., Ed.; Gen. Tech. Rep. IITF-GTR-26; US Department of Agriculture, International Institute of Tropical Forestry, Rocky Mountain Research Station: San Juan, PR, USA; Fort Collins, CO, USA, 2004; Volume 1, pp. 167-169.

12. Hayward, C.L. Biotic communities of the Wasatch chaparral, Utah. Ecol. Monogr. 1948, 18, 473-506. [CrossRef]

13. DeBolt, A.M.; McCune, B. Is netleaf hackberry a viable rehabilitation species for Idaho rangelands? In Proceedings: Wildland Shrub and Arid Land Restoration Symposium; Roundy, B.A., McArthur, E.D., Haley, J.S., Mann, D.K., Eds.; Gen. Tech. Rep. INT-GTR-315; U.S. Department of Agriculture: Ogden, UT, USA, 1995; pp. 305-309.

14. DeBolt, A.M.; McCune, B. Ecology of Celtis reticulata in Idaho. Great Basin Nat. 1995, 55, 237-248.

15. Bonner, F.T. Celtis L. hackberry. In Seeds of Woody Plants in the United States, Handbook 450; Shopmeyer, C.S., Ed.; U.S. Department of Agriculture: Washington, DC, USA, 1974; pp. 298-300. 
16. DeBolt, A.M. The Ecology of Celtis reticulata Torr. (Netleaf Hackberry) in Idaho. Master's Thesis, Oregon State University, Corvallis, OR, USA, 1992.

17. Stevens, M.T.; Holland, D.L.; Tanner, N.V. Netleaf hackberry seeds planted near boulders in the foothills of the Wasatch Mountains: Germination, survival, and patterns of establishment. West. N. Am. Nat. 2016, 76, 452-458. [CrossRef]

18. Stevens, M.T.; Holland, D.L. Germination of netleaf hackberry seeds on the north sides of boulders: A shift away from patterns of mature hackberry distribution? West. N. Am. Nat. 2017, 77, 272-274. [CrossRef]

19. Lewis Ivey, M.L.; Adkikari, A.; Graham, C.; Malekian, F.; Fontenot, K. Vegetable Seed Sanitation: Best Practices to Ensure On-farm Food Safety; Louisiana Department of Agriculture and Forestry: Baton Rouge, LA, USA, 2015; pp. 1-2.

20. Traveset, A.; Robertson, A.; Rodríguez-Pérez, J. A review on the role of endozoochory in seed germination. In Seed Dispersal: Theory and Its Application in a Changing World; Dennis, A.J., Schupp, E.W., Green, R.J., Westcott, D.A., Eds.; CAB International: Wallingford, UK, 2007; pp. 78-103.

21. Traveset, A.; Riera, N.; Mas, R.E. Ecology of fruit-colour polymorphism in Myrtus communis and differential effects of birds and mammals on seed germination and seedling growth. J. Ecol. 2001, 89, 749-760. [CrossRef]

22. Traveset, A.; Verdú, M. A meta-analysis of the effect of gut treatment on seed germination. In Seed Dispersal and Frugivory: Ecology, Evolution, and Conservation; Levey, D.J., Silva, W.R., Galetti, M., Eds.; CAB International: Wallingford, UK, 2002; pp. 339-350.

23. Cypher, B.L.; Cypher, E.A. Germination rates of tree seeds ingested by coyotes and raccoons. Am. Midl. Nat. 1999, 142, 71-76. [CrossRef]

24. Harper, J.L. Population Biology of Plants; Academic Press: New York, NY, USA, 1977.

25. Verdú, M.; Traveset, A. Early emergence enhances plant fitness: A phylogenetically controlled meta-analysis. Ecology 2005, 86, 1385-1394. [CrossRef]

26. de Luis, M.; Verdú, M.; Raventós, J. Early to rise makes a plant healthy, wealthy, and wise. Ecology 2008, 89, 3061-3071. [CrossRef]

27. Schupp, E.W. Quantity, quality and the effectiveness of seed dispersal by animals. Vegetatio 1993, 107, 15-29.

28. Ross, M.A.; Harper, J.L. Occupation of biological space during seedling establishment. J. Ecol. 1972, 60, 77-88. [CrossRef]

29. Seiwa, K. Advantages of early germination for growth and survival of seedlings of Acer mono under different overstorey phenologies in deciduous broad-leaved forests. J. Ecol. 1998, 86, 219-228. [CrossRef]

30. Moreno, J.; Oechel, W. Factors controlling postfire seedling establishment in southern California chaparral. Oecologia 1992, 90, 50-60. [CrossRef] [PubMed]

31. Seiwa, K. Effects of seed size and emergence time on tree seedling establishment: Importance of developmental constraints. Oecologia 2000, 123, 208-215. [CrossRef] [PubMed]

32. Castro, J. Short delay in timing of emergence determines establishment success in Pinus sylvestris across microhabitats. Ann. Bot. 2006, 98, 1233-1240. [CrossRef] [PubMed]

33. Mathias, A.; Kisdi, E. Adaptive diversification of germination strategies. Proc. Roy. Soc. B-Biol. Sci. 2002, 269, 151-155. [CrossRef] [PubMed]

34. Kozlowski, T.T. Growth and Development of Trees; Seed Germination, Ontogeny and Shoot Growth; Academic Press: New York, NY, USA, 1971; Volume 1, pp. 164-206.

35. Peattie, D.C. A Natural History of Western Trees; Houghton Mifflin Harcourt: Boston, MA, USA, 1991.

36. Lanner, R.M. Trees of the Great Basin: A Natural History; University of Nevada Press: Reno, NV, USA, 1984.

(C) 2020 by the authors. Licensee MDPI, Basel, Switzerland. This article is an open access article distributed under the terms and conditions of the Creative Commons Attribution (CC BY) license (http://creativecommons.org/licenses/by/4.0/). 